\title{
CDK3 Gene
}

National Cancer Institute

\section{Source}

National Cancer Institute. CDK3 Gene. NCI Thesaurus. Code C24286.

This gene is involved in cell cycle checkpoints. 